\title{
Cardiovascular effects of histamine in three widely diverse species of reptiles
}

\author{
Nini Skovgaard ${ }^{1,2}$ (1) $\cdot$ Augusto S. Abe $^{2}$ Edwin W. Taylor ${ }^{2,3} \cdot$ Tobias Wang $^{1,2}$
}

Received: 30 March 2017 / Revised: 11 May 2017 / Accepted: 13 May 2017 / Published online: 10 July 2017

(C) Springer-Verlag Berlin Heidelberg 2017

\begin{abstract}
The cardiovascular system of vertebrates is regulated by a vast number of regulatory factors, including histamine. In pythons, histamine induces a strong tachycardia and dilates the systemic vasculature, which resembles the cardiovascular response to the elevated metabolic rate during digestion. In fact, there is an important role of increased histaminergic tone on the heart during the initial $24 \mathrm{~h}$ of digestion in pythons. Whilst the cardiovascular effects of histamine are well studied in pythons, little is known about the effects in other groups of reptiles. The histaminergic effects on the heart vary among species and histamine may exert either pressor and depressor effects by causing either constrictive or dilatory vascular responses. Here, we investigated the cardiovascular effects of histamine in three species of reptiles with very different cardiovascular and pulmonary morphologies. Experiments were performed on both anesthetized and recovered animals. We show a species-dependent effect of histamine on the systemic vasculature with dilation in rattlesnakes and constriction in turtles and caimans but no effect on the pulmonary circulation. The histamine-induced dilation in rattlesnakes was mediated through an activation of $\mathrm{H}_{2}$-receptors, whereas the histamine-induced constriction in caimans was mediated
\end{abstract}

Communicated by H.V. Carey.

Nini Skovgaard

nini.jensen@bios.au.dk

1 Zoophysiology, Department of Bioscience, Aarhus University, C.f. Møllers Allé 3, Building 1131, 8000 Aarhus C, Denmark

2 Departamento de Zoologia, Centro de Aquicultura, UNESP, Rio Claro, Brazil

3 School of Biosciences, University of Birmingham, Birmingham, UK through both adrenergic signaling and $\mathrm{H}_{1}$-receptors activation. In all three species, histamine-induced tachycardia by direct stimulation of histaminergic receptors as well as an indirect activation of adrenoreceptors. This finding highlights a more complex mechanism underlying the action of histamine than previously recognized in reptiles.

Keywords Heart rate - Vascular resistance - Adrenergic . Histaminergic $\cdot$ Histamine receptor

\section{Introduction}

Regulation of the cardiovascular system serves to match oxygen and nutrient supplies to the metabolic demands of the tissues during a plethora of physiological states, such as physical activity, digestion, temperature variation, and hypoxia. Similar to mammals, the cardiovascular system of reptiles is governed by continuous autonomic nervous regulation by excitatory adrenergic, sympathetic innervation plus inhibitory cholinergic, and parasympathetic innervation (Morris and Nilsson 1994). In addition, vascular resistance, heart rate, and stroke volume are regulated by circulating hormones, local factors, such as endothelium derived constrictors or dilators, respiratory gases, metabolites, and vasoactive substances in both blood and tissues. One such regulatory factor is histamine (Dale and Laidlaw 1910; Bristow et al. 1982).

Histamine is a biogenic amine formed by the decarboxylation of L-histidine (Schayer 1956). It is stored and released from tissue mast cells, basophil leucocytes, and specialized non-mast cells in the gastric mucosa (Reite 1972). In addition, histamine is both stored and released from neurons within the central and peripheral nervous systems (Miki et al. 1992; Hegedüs et al. 2004; Li et al. 2006). The whole body 
content of histamine is high in amniotes (mammals, birds, and reptiles), but low in amphibians and most fish, which has been ascribed to variation in the histamine content of mast cells and basophil leucocytes (Reite 1972). In mammals, histamine exerts a wide array of cardiovascular effects, including dilation of the systemic vasculature as well as a direct positive chronotropic and inotropic effect on the heart (Bristow et al. 1982).

In pythons, histamine is a non-adrenergic non-cholinergic (NANC) humoral factor, which dilates the systemic vasculature and stimulates heart rate (Skovgaard et al. 2009; Enok et al. 2012). Histamine induces tachycardia upon direct binding to $\mathrm{H}_{2}$-receptors and through a reinforcement of adrenergic signaling, which acts in concert with a reduced cholinergic stimulation and one or more other circulating NANC factor(s) (Wang et al. 2001; Skovgaard et al. 2009; Nørgaard et al. 2017). Overall, these histaminergic effects resemble the cardiovascular response to the elevated metabolic rate during digestion, and we have previously documented an important role of increased histaminergic tone on the heart during the initial $24 \mathrm{~h}$ of digestion (Skovgaard et al. 2009).

Whilst the cardiovascular effects of histamine are well studied in pythons, little is known about the effects in other groups of reptiles. The histaminergic effects on the heart vary among species, and histamine may exert either pressor and depressor effects by causing either constrictive or dilatory vascular responses (Reite 1970, 1972; Ojewole and Akinwande 1984; Kiniwa and Tasaka 1989). Histamine also plays a role in regulation of blood pressure and heart rate in late stage embryos of the red-footed tortoise, Chelonoidis carbonaria (Crossley et al. 2013). Nevertheless, the effects have not been studied in detail. In the present study, we evaluate the hemodynamic effects of histamine in the systemic and pulmonary circulation of three species of reptiles: fresh water turtle, rattlesnake, and caiman that represent widely diverse orders of the Class Reptilia: Chelonia, Squamata, and Crocodilia, respectively, having very different cardiovascular and pulmonary morphologies (Hicks 1998; Wang et al. 1998). Moreover, we investigate the mechanism underlying the cardiovascular effects through pharmacological blockade of the autonomic nervous system as well as histaminergic receptors. Experiments were primarily performed on anesthetized animals, but we also measured blood pressures responses in caimans and rattlesnakes that had recovered from surgery and anesthesia.

\section{Materials and methods}

\section{Experimental animals}

Experiments were undertaken on 7 yellow-spotted Amazon River turtles (Podocnemis unifilis; Troschel,
1848) $(0.57 \pm 0.03 \mathrm{~kg}$; mean \pm SEM $), 10$ South American rattlesnakes (Crotalus durissus; Linnaeus, 1758) $(0.69 \pm 0.05 \mathrm{~kg})$, and 11 broad-snouted caimans (Caiman latirostris; Daudin, 1801) (1.46 $\pm 0.08 \mathrm{~kg})$. Turtles were collected soon after hatching in Central Brazil (State of Goías) and raised in captivity at UNESP, Rio Claro, Brazil. Rattlesnakes were obtained from the Butantan Institute (São Paulo, Brazil) and transported to UNESP. Caimans were captive-bred at UNESP, where all experiments were conducted. All animals appeared healthy and were kept at $27 \pm 5^{\circ} \mathrm{C}$. With the exception of the rattlesnakes, the experimental animals were maintained in outdoor enclosures with access to both water and dry areas, and they experienced natural temperatures and light regimes. The rattlesnakes had been maintained in terraria at temperatures ranging from 25 to $30^{\circ} \mathrm{C}$ for several weeks. All animals fed voluntarily and appeared to be in good health. Experiments were carried out according to Brazilian and Danish Federal Regulations.

\section{Surgery and instrumentation for studies on anesthetized animals}

All terminally anesthetized specimens were given an intramuscular injection of sodium pentobarbital (Mebumal, Sygehusapotekerne, Denmark). The doses administered were: rattlesnakes, $30 \mathrm{mg} \mathrm{kg}^{-1}$; turtles and caimans, $50 \mathrm{mg} \mathrm{kg}^{-1}$, with caimans and turtles given a supplemental dose of $25 \mathrm{mg} \mathrm{kg}^{-1}$ if corneal and pedal withdrawal reflexes persisted after $1 \mathrm{~h}$. Caimans were then intubated, whereas rattlesnakes and turtles were tracheostomized for artificial ventilation. In all species, a mechanical ventilator (Harvard Apparatus) was used for ventilation (5-10 breaths $\min ^{-1}$ and a tidal volume of $15-40 \mathrm{ml} \mathrm{kg}^{-1}$ ). Because of anatomical differences, the instrumentation of the three species varied.

\section{Anesthetized turtles}

A $3 \times 4 \mathrm{~cm}$ piece of the plastron was removed using a bone saw to expose the central blood vessels. For measurements of systemic blood pressure $\left(P_{\text {sys }}\right)$, the left subclavian artery was occlusively cannulated with a PE50 catheter filled with heparinized saline $\left(50 \mathrm{IU} \mathrm{ml}^{-1}\right)$. For measurements of blood flow, 1R transit-time ultrasonic blood flow probes (Transonic System, Inc., Ithaca, NY, USA) were placed around the left aortic arch (LAo) and the right pulmonary artery. Acoustical gel was infused around the blood flow probes to enhance the signal. 
Anesthetized rattlesnakes

A $5 \mathrm{~cm}$ ventral incision was made above the heart. The vertebral artery and a small branch of the pulmonary artery supplying the lower part of the lung were occlusively cannulated with PE50 catheter for measurements of $P_{\text {sys }}$ and $P_{\text {pul }}$, respectively. Transonic blood flow probes (1 or $\left.1.5 \mathrm{R}\right)$ were placed around the left aortic arch and pulmonary artery.

\section{Anesthetized caimans}

In six caimans, a $5 \mathrm{~cm}$ ventral incision was made through the sternum to access central blood vessels. For measurements of $P_{\text {sys, }}$ the right carotid artery was occlusively cannulated, and for measurements of $P_{\text {pul, }}$ the left pulmonary artery was non-occlusively cannulated with an intravenous catheter (Terumo Surflo, Belgium) using the Seldinger technique (White et al. 1989). Transonic blood flow probes (1.5R) were placed around the left pulmonary arch and the right aortic arch.

\section{Surgery and instrumentation for studies on animals recovered from anesthesia}

\section{Rattlesnakes}

In four snakes, anesthesia was induced by inhalation of Isofluran (Isofluran, Baxter, Denmark). The animals were then cannulated with a PE50 catheter into the vertebral artery. The catheter was externalized, the incision closed, and the snakes were allowed to recover from surgery in a box in a climatic chamber at $25^{\circ} \mathrm{C}$ until the following day.

\section{Recovered caimans}

Six caimans were cannulated in the right femoral artery with a PE50 catheter under local anesthesia (Lidocaine $\left.1 \%, 1 \mathrm{ml} \mathrm{kg}^{-1}\right)$. The catheter was externalized, the incision closed, and the animals were allowed to recover in a climatic chamber at $25^{\circ} \mathrm{C}$ for $24 \mathrm{~h}$ before the onset of experimental protocol.

\section{Measurements of flows and pressures}

All catheters were connected to Baxter Edward (model PX600, Irvine, CA, USA) disposable pressure transducers, and the signals were amplified using an in-house built preamplifier. Flow probes were connected to a Transonic dualchannel blood flow meter (T206, Transonic System, Inc., Ithaca, NY, USA). Signals from the pressure transducers and the blood flow meter were recorded with a Biopac MP100 data acquisition system (Biopac Systems, Inc., Goleta, CA, USA) at $100 \mathrm{~Hz}$.

\section{Experimental protocols}

\section{Studies on anesthetized animals}

Hemodynamic variables were recorded for 45 min after instrumentation to obtain basal values upon recovery from surgical stress. A stock solution of histamine $\left(10^{-3} \mathrm{M}\right)$ was prepared and serial dilutions to appropriate concentration were made using $0.9 \% \mathrm{w} / \mathrm{v}$ isotonic saline; all drugs were given in $1.0 \mathrm{ml} \mathrm{kg} \mathrm{m}^{-1}$ aliquots. A sham injection of saline was given to evaluate whether the vehicle affected hemodynamic variables. All experiments were carried out at $25 \pm 3^{\circ} \mathrm{C}$.

\section{Anesthetized turtles}

All six turtles received a series of intra-arterial bolus injections of increasing doses of histamine: $0.01,0.1,1,3,10$, 30,100 , and $300 \mathrm{nmol} \mathrm{kg}^{-1}$. Hemodynamic variables were allowed to return to baseline levels between each injection. To establish whether a basal histamine tone was present and to evaluate which receptor subtypes might be involved in the response, bolus injections of an $\mathrm{H}_{1}$-receptor antagonist [pyrilamine maleate salt (mepyramine), $20 \mathrm{mg} \mathrm{kg}^{-1}$ ] and $\mathrm{H}_{2}$-receptor antagonist (ranitidine hydrochloride, $20 \mathrm{mg}$ $\mathrm{kg}^{-1}$ ) were given. The order of administration of antagonists was alternated, and the antagonists were allowed to take effect for $20 \mathrm{~min}$ before subsequent injections.

\section{Anesthetized rattlesnakes}

A pharmacological blockade of muscarinic receptors with a bolus injection of atropine $\left(3 \mathrm{mg} \mathrm{kg}^{-1}\right)$ was given to exclude the possibility that effects of histamine on heart rate were due to a withdrawal of vagal tone. Six rattlesnakes received a series of intra-arterial bolus injections of histamine: 1, 3, 10, 30, 100, 300, 1000, and $3000 \mathrm{nmol}$ $\mathrm{kg}^{-1} \cdot \mathrm{H}_{1}$ - and $\mathrm{H}_{2}$-receptor antagonists (mepyramine and ranitidine, $20 \mathrm{mg} \mathrm{kg}^{-1}$, respectively) were administered in alternating sequence, and the agents were allowed to take effect for $20 \mathrm{~min}$ before any subsequent injection.

\section{Anesthetized caimans}

To ascertain that no vagal tone was present despite terminal anesthesia, a bolus injection of atropine $\left(3 \mathrm{mg} \mathrm{kg}^{-1}\right)$ was given. Six caimans then received a series of intra-arterial bolus injections of histamine: $1,3,10,30,100,300$, and $1000 \mathrm{nmol} \mathrm{kg}{ }^{-1} \cdot \mathrm{H}_{2}$-receptor antagonist (ranitidine, $20 \mathrm{mg}$ 
$\mathrm{kg}^{-1}$ ) was administered and was allowed to take effect for $20 \mathrm{~min} . \mathrm{H}_{1}$-receptor antagonist in full (mepyramine, $20 \mathrm{mg}$ $\left.\mathrm{kg}^{-1}\right)$ and half $\left(10 \mathrm{mg} \mathrm{kg}^{-1}\right)$ dose stopped the heart immediately and no data were obtained.

\section{Experiments on animals recovered from anesthesia and surgery}

In addition to the experiments described above, we measured blood pressure responses on a separate group of rattlesnakes and caimans after they had recovered from anesthesia and surgery. These animals were kept in boxes within a climatic chamber at $25^{\circ} \mathrm{C}$ during the entire experiment, where they were shielded from visual and auditory disturbances. Resting values of blood pressure and heart rate were obtained 1 to $2 \mathrm{~h}$ after having connected the catheters.

\section{Recovered rattlesnakes}

Four rattlesnakes were given bolus injections of histamine $\left(300 \mathrm{nmol} \mathrm{kg}^{-1}\right)$ before and after a double adrenergic blockade (phentolamine and propranolol, $3 \mathrm{mg} \mathrm{kg}^{-1}$, respectively), before and after an $\mathrm{H}_{1}$-receptor antagonist (mepyramine, $20 \mathrm{mg} \mathrm{kg}^{-1}$ ) and before and after an $\mathrm{H}_{2}$-receptor antagonist (ranitidine, $20 \mathrm{mg} \mathrm{kg}^{-1}$ ).

\section{Recovered caimans}

Five caimans were given bolus injections of histamine before and after double adrenergic blockade and an $\mathrm{H}_{1}$-receptor antagonist in the following order: histamine $\left(100 \mathrm{nmol} \mathrm{kg}^{-1}\right)$, phentolamine $\left(3 \mathrm{mg} \mathrm{kg}^{-1}\right)$, propranolol $\left(3 \mathrm{mg} \mathrm{kg}^{-1}\right)$, histamine $\left(100 \mathrm{nmol} \mathrm{kg}^{-1}\right), \mathrm{H}_{1}$-receptor antagonist (pyrilamine maleate salt, $20 \mathrm{mg} \mathrm{kg}^{-1}$ ), and histamine $\left(100 \mathrm{nmol} \mathrm{kg}^{-1}\right)$.

\section{Calculation of blood flows, stroke volume, and vascular conductances}

Because there is only one pulmonary artery in the rattlesnake, measurements of blood flow in the pulmonary artery represent total pulmonary blood flow $\left(Q_{\mathrm{pul}}\right)$ (Taylor et al. 2009). $Q_{\text {pul }}$ in caimans and turtles was calculated as two times blood flow in the left and right pulmonary artery, respectively, under the assumption that pulmonary blood flow is distributed evenly between left and right pulmonary arteries. Heart rate $\left(f_{\mathrm{H}}\right)$ was calculated from the instantaneous blood flow trace.

When baseline blood flow changes more than baseline blood pressure, which is the case in most in vivo situations, conductance provides a better index for comparing vascular tone than resistance (Lautt 1989; O'Leary 1991). Pulmonary and systemic conductances $\left(G_{\text {pul }}\right.$ and
$G_{\text {sys }}$, respectively) were calculated from mean blood flow and mean blood pressure $\left(G_{\mathrm{pul}}=Q_{\mathrm{pul}} / P_{\mathrm{pul}}\right.$ and $G_{\mathrm{sys}}=$ $\left.Q_{\text {sys }} / P_{\text {sys }}\right)$ assuming that central venous blood pressures are negligible.

\section{Data analysis and statistics}

All recordings of blood flows and pressures were analyzed using the AcqKnowledge data analysis software (version 3.7.1., Biopac, Goleta, CA, USA). Mean blood pressures and flows were taken over a $1 \mathrm{~min}$ period prior to and at the maximum effect of histamine. Effects were assessed by a one-way ANOVA for repeated measurements followed by a Holm-Sidak post hoc test to identify values that were significantly different from control values. Differences were considered statistically significant at a $95 \%$ level of confidence $(P<0.05)$. All data are presented as mean \pm SEM.

\section{Results}

\section{Dose-dependent hemodynamic effects of histamine in turtles, rattlesnakes, and caimans}

The hemodynamic effects of histamine on the systemic circulation in anesthetized turtles, rattlesnakes, and caimans are shown in Fig. 1. In turtles, histamine exerted a dosedependent systemic constriction apparent as a decrease in systemic conductance and associated with hypertension (Fig. 1a, c), whereas $Q_{\mathrm{LAo}}$ (Fig. 1b) and $Q_{\text {pul }}$ (data not shown) remained largely unchanged. There was a substantial dose-dependent tachycardia, although the response was attenuated at the highest doses, possibly due to tachyphylaxia (Fig. 1d). In rattlesnakes, systemic dilation upon histamine injection was associated with a decline in $P_{\text {sys }}$ and increase in $G_{\text {sys }}$ (Fig. 1e,g), whereas $Q_{\mathrm{LAo}}$ was unchanged (Fig. 1f). The induced right-to-left cardiac shunt caused a reduction in $P_{\text {pul }}$ and $Q_{\text {pul }}$ leaving $\mathrm{G}_{\text {pul }}$ unchanged (data not shown). There was a small increase in $f_{\mathrm{H}}$ (Fig. 1h). In caimans, injections of histamine caused a dose-dependent (100-1000 nmol kg-1) biphasic response in $f_{\mathrm{H}}$ with an initial bradycardia followed by tachycardia (Fig. 1d). The subsequent tachycardia was associated with increased $P_{\text {sys }}$ (Fig. 1i). Histamine did not affect the pulmonary circulation (data not shown) or $Q_{\text {RAo }}$ (Fig. 1j) and caused only a small systemic constriction at the highest dose (Fig. 1k).

\section{Effects of $\mathrm{H}_{1}$ - and $\mathrm{H}_{2}$-receptor antagonists}

Hemodynamic responses to specific $\mathrm{H}_{1}$ - and $\mathrm{H}_{2}$-receptor blockade in anesthetized turtles, rattlesnakes, and caimans are listed in Table 1 . In turtles, $\mathrm{H}_{1}$-receptor blockade had no effects on $P_{\text {sys }}, Q_{\text {sys, }}$ and $G_{\text {sys }}$, but caused a 
Fig. 1 Hemodynamic effects in anesthetized turtles, rattlesnakes, and caimans of bolus intra-arterial injections of histamine on the maximum change in mean systemic pressure, $P_{\text {sy }}$ (a, e, i); mean systemic blood flow, $Q_{\text {sys* }}(\mathbf{b}, \mathbf{f}, \mathbf{j})$; systemic vascular conductance, $G_{\text {sys }}$ (c, $\mathbf{g , ~ k})$ and heart rate, $f_{\mathrm{H}}(\mathbf{d}, \mathbf{h}$, l), as a function of the amount of histamine injected. $Q_{\text {sys*: }}$ : left aortic blood flow $\left(Q_{\mathrm{LAo}}\right)$ in turtles and rattlesnakes, right aortic blood flow $\left(Q_{\mathrm{RAo}}\right)$ in caimans. The heart rate responses of caimans to histamine were biphasic; for the animals, the black symbols represent the primary decrease in heart rate, whilst the open symbols depict the subsequent bradycardia. Data points show means \pm SEM $N=6-7$. *Denotes a significant difference $(P<0.05)$ from preinjection value evaluated by a one-way ANOVA for repeated measures followed by a HolmSidak post hoc test
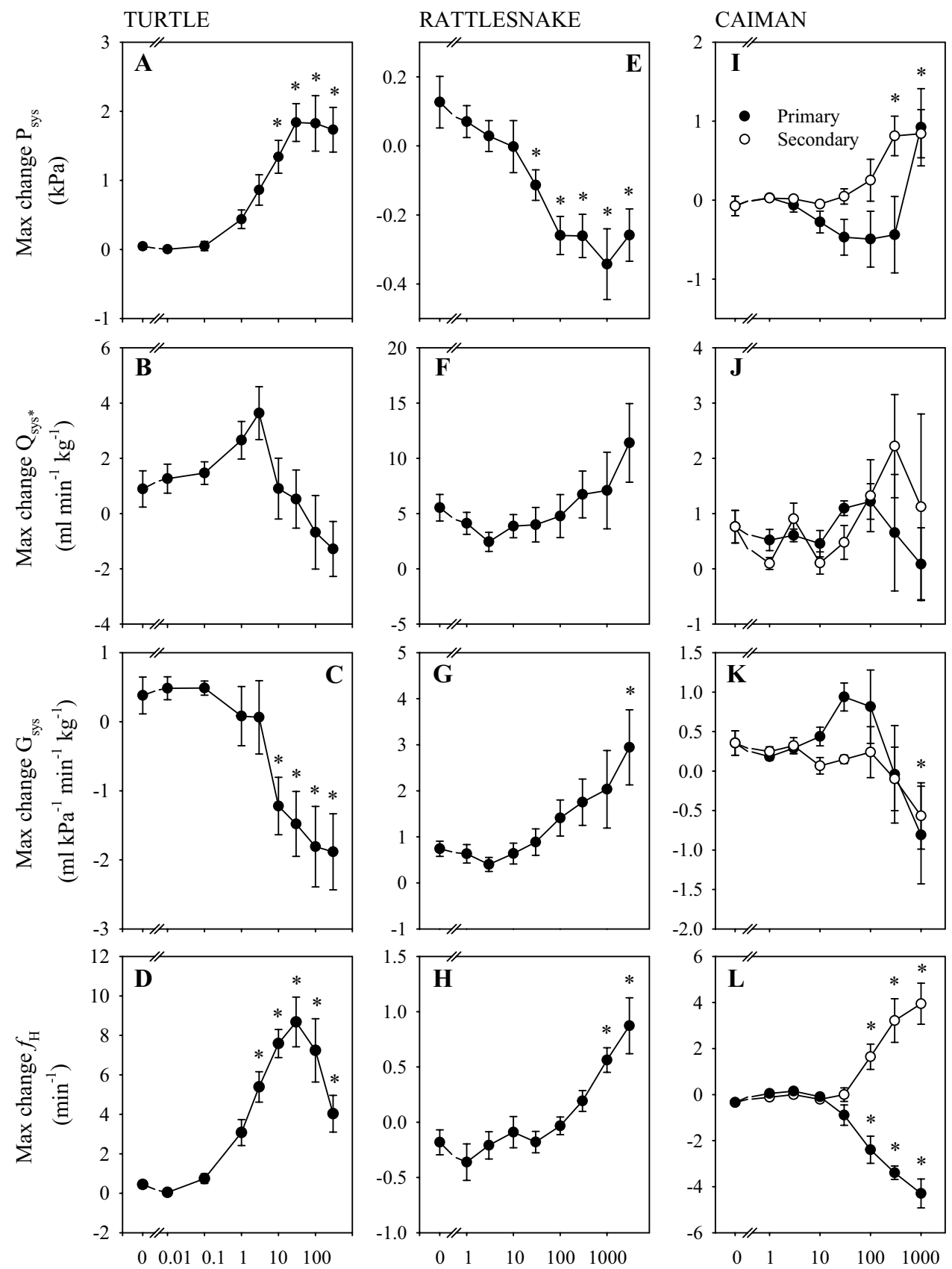

Histamine (nmol kg-1) reduction in $f_{\mathrm{H}}$ with an accompanying rise in $Q_{\mathrm{pul}}$. The only effect of $\mathrm{H}_{2}$-receptor blockade was an increase in $P_{\text {sys }}$. In anesthetized rattlesnakes, the $\mathrm{H}_{1}$-receptor antagonist reduced both systemic and pulmonary conductances together with an increase in $P_{\mathrm{sys}}, P_{\mathrm{pul}}$, and $Q_{\text {pul }}$. Infusion of the $\mathrm{H}_{2}$-receptor antagonist in anesthetized and recovered rattlesnakes increased $f_{\mathrm{H}}$. In recovered rattlesnakes, the $\mathrm{H}_{1}$-receptor antagonist had no effect. In anesthetized caimans, $\mathrm{H}_{2}$-receptor blockade caused a decrease in $f_{\mathrm{H}}$, but there were no effects in the pulmonary and systemic circulations. $\mathrm{H}_{1}$-receptor infusion had no effects in recovered caimans.

\section{Effects of histamine before and after adrenergic and histamine receptor block}

In recovered rattlesnakes (Fig. 2a, b), a bolus injection of histamine $\left(300 \mathrm{nmol} \mathrm{kg}^{-1}\right)$ increased $f_{\mathrm{H}}(14.0 \pm$ $3.5 \mathrm{~min}^{-1}$ ) and caused a small reduction in blood pressure $(-0.28 \pm 0.47 \mathrm{kPa})$. Blocking alpha- and beta-adrenergic 
Table 1 Hemodynamic effects of histamine $\mathrm{H}_{1}$ - and $\mathrm{H}_{2}$-receptor antagonists in anesthetized and recovered yellow-spotted Amazon River turtle (Podocnemis unifilis), South American rattlesnake (Crotalus durissus), and broad-snouted caiman (Caiman latirostris)

\begin{tabular}{|c|c|c|c|c|c|c|c|}
\hline & $P_{\text {sys }}(\mathrm{kPa})$ & $Q_{\text {sys }}{ }^{\mathrm{a}}\left(\mathrm{ml} \mathrm{min}{ }^{-1} \mathrm{~kg}^{-1}\right)$ & $\begin{array}{l}G_{\text {sys }}(\mathrm{ml} \mathrm{kPa} \\
\left.\min ^{-1} \mathrm{~kg}^{-1}\right)\end{array}$ & $P_{\text {pul }}(\mathrm{kPa})$ & 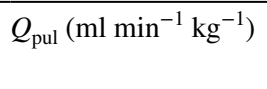 & $\begin{array}{l}G_{\text {pul }}(\mathrm{ml} \mathrm{kPa} \\
\left.\min ^{-1} \mathrm{~kg}^{-1}\right)\end{array}$ & $\overline{f_{\mathrm{H}}\left(\min ^{-1}\right)}$ \\
\hline \multicolumn{8}{|l|}{ Turtle } \\
\hline \multicolumn{8}{|l|}{ Anesthetized } \\
\hline Control & $1.45 \pm 0.23$ & $3.35 \pm 1.26$ & $2.10 \pm 0.60$ & & $12.07 \pm 2.62$ & & $41.7 \pm 2.3$ \\
\hline $\mathrm{H}_{1}$-antagonist & $1.82 \pm 0.11$ & $3.63 \pm 0.74$ & $2.12 \pm 0.47$ & & $17.56 \pm 4.77 *$ & & $33.5 \pm 3.0^{*}$ \\
\hline Control & $1.86 \pm 0.12$ & $3.98 \pm 1.14$ & $2.07 \pm 0.48$ & & $15.64 \pm 3.77$ & & $40.4 \pm 3.4$ \\
\hline $\mathrm{H}_{2}$-antagonist & $2.19 \pm 0.14 *$ & $5.07 \pm 0.80$ & $2.35 \pm 0.35$ & & $24.12 \pm 7.95$ & & $38.3 \pm 2.3$ \\
\hline \multicolumn{8}{|l|}{ Rattlesnake } \\
\hline \multicolumn{8}{|l|}{ Recovered } \\
\hline Control & $2.67 \pm 0.24$ & & & & & & $30.7 \pm 4.5$ \\
\hline $\mathrm{H}_{1}$-antagonist & $3.16 \pm 0.34$ & & & & & & $23.2 \pm 6.0$ \\
\hline Control & $3.18 \pm 0.23$ & & & & & & $30.7 \pm 1.7$ \\
\hline $\mathrm{H}_{2}$-antagonist & $3.23 \pm 0.36$ & & & & & & $36.0 \pm 2.0^{*}$ \\
\hline \multicolumn{8}{|l|}{ Anesthetized } \\
\hline Control & $5.37 \pm 0.39$ & $50.78 \pm 4.10$ & $9.19 \pm 1.11$ & $3.76 \pm 0.35$ & $52.56 \pm 7.18$ & $13.80 \pm 0.91$ & $49.7 \pm 2.0$ \\
\hline $\mathrm{H}_{1}$-antagonist & $7.22 \pm 0.41^{*}$ & $48.02 \pm 5.44$ & $6.79 \pm 1.16^{*}$ & $5.14 \pm 0.37 *$ & $63.19 \pm 5.03^{*}$ & $12.48 \pm 1.05^{*}$ & $47.7 \pm 2.3$ \\
\hline Control & $6.09 \pm 0.73$ & $53.70 \pm 6.68$ & $10.20 \pm 1.90$ & $4.02 \pm 0.54$ & $56.80 \pm 5.67$ & $13.08 \pm 1.11$ & $48.4 \pm 2.5$ \\
\hline $\mathrm{H}_{2}$-antagonist & $5.99 \pm 0.46$ & $51.48 \pm 4.94$ & $9.03 \pm 1.16$ & $4.02 \pm 0.44$ & $55.59 \pm 7.96$ & $13.70 \pm 0.92$ & $51.1 \pm 2.1 *$ \\
\hline \multicolumn{8}{|l|}{ Caiman } \\
\hline \multicolumn{8}{|l|}{ Recovered } \\
\hline Control & $4.58 \pm 0.45$ & & & & & & $20.7 \pm 3.3$ \\
\hline $\mathrm{H}_{1}$-antagonist & $4.44 \pm 0.57$ & & & & & & $20.7 \pm 3.0$ \\
\hline \multicolumn{8}{|l|}{ Anaesthetised } \\
\hline Control & $2.40 \pm 0.60$ & $5.04 \pm 0.67$ & $2.46 \pm 0.16$ & $1.51 \pm 0.19$ & $4.81 \pm 1.92$ & $3.21 \pm 1.61$ & $29.8 \pm 2.0$ \\
\hline $\mathrm{H}_{2}$-antagonist & $2.70 \pm 0.67$ & $4.83 \pm 1.11$ & $2.07 \pm 0.22$ & $1.62 \pm 0.33$ & $3.72 \pm 1.86$ & $2.48 \pm 1.30$ & $28.6 \pm 2.3^{*}$ \\
\hline
\end{tabular}

Values are means \pm SEM

$\mathrm{H}_{1}$-receptor antagonist (mepyramine), $20 \mathrm{mg} \mathrm{kg}^{-1}$ and $\mathrm{H}_{2}$-receptor antagonist (ranitidine), $20 \mathrm{mg} \mathrm{kg}^{-1}$

$P_{s y s}$ systemic blood pressure, $G_{s y s}$ systemic conductance, $P_{p u l}$ pulmonary blood pressure, $Q_{p u l}$ pulmonary blood flow, $G_{p u l}$ pulmonary conductance, $f_{H}$ heart rate

* Significant difference between values before and after administration $(P<0.05)$

${ }^{\mathrm{a}}$ Turtles and Rattlesnakes, $Q_{\mathrm{LAo}}$, left aortic blood flow; Caimans, $Q_{\mathrm{RAo}}$, right aortic blood flow

receptors with phentolamine and propranolol, respectively, caused a large reduction in the histamine-induced tachycardia $\left(4.3 \pm 1.7 \mathrm{~min}^{-1}\right)$. Adrenergic blockade had no effect on blood pressure. Blocking histamine $\mathrm{H}_{1}$-receptors had no effects on $f_{\mathrm{H}}$ or blood pressure. The histamine $\mathrm{H}_{2}$-receptor antagonist completely blocked the effect of histamine on $f_{\mathrm{H}}$ $\left(-0.1 \pm 0.2 \mathrm{~min}^{-1}\right)$ and changed the small depressor effect to a small pressor effect $(0.33 \pm 0.11 \mathrm{kPa})$, although this was not statistically significant likely due to the small $N$ value $(N=4)$.

In recovered caimans (Fig. 2c, d), a bolus injection of $100 \mathrm{nmol} \mathrm{kg} \mathrm{kg}^{-1}$ histamine led to an increase in $f_{\mathrm{H}}(5.0 \pm$ $\left.1.5 \mathrm{~min}^{-1}\right)$ and blood pressure $(1.21 \pm 0.24 \mathrm{kPa})$, which was attenuated after double adrenergic blockade $(2.4 \pm$ $1.1 \mathrm{~min}^{-1}$ and $\left.0.71 \pm 0.1 \mathrm{kPa}\right)$. Injection of the $\mathrm{H}_{1}$-receptor antagonist reversed the pressor effect of histamine to a slight depressor effect $(-0.16 \pm 0.15 \mathrm{kPa})$ and further reduced the effect of histamine on $f_{\mathrm{H}}\left(0.8 \pm 0.3 \mathrm{~min}^{-1}\right.$, $P=0.06)$.

\section{Discussion}

The data revealed a species-dependent effect of histamine on the systemic vasculature, with dilation in rattlesnakes, whilst turtles and caimans exhibited constriction. There were no responses to histamine in the pulmonary circulation of either species. The histamine-induced dilation in rattlesnakes was mediated by activation of $\mathrm{H}_{2}$-receptors, whereas the histamine-induced constriction was mediated through both adrenergic signaling and $\mathrm{H}_{1}$-receptors activation in caimans. In all three species, histamine-induced tachycardia by direct stimulation of histaminergic receptors as well as an indirect activation of adrenoreceptors. This 
Fig. 2 Effects of histamine in recovered rattlesnakes $\left(300 \mathrm{nmol} \mathrm{kg}^{-1}\right)$ and caimans $\left(100 \mathrm{nmol} \mathrm{kg}^{-1}\right)$ on maximum change in mean systemic blood pressure, $P_{\text {sys, }}(\mathbf{a}, \mathbf{c})$ and heart rate, $f_{\mathrm{H}}(\mathbf{b}, \mathbf{d})$ before and after double adrenergic blockade (phentolamine and propranolol, $3 \mathrm{mg} \mathrm{kg}^{-1}$, respectively), $\mathrm{H}_{1}$-receptor block (mepyramine, $20 \mathrm{mg} \mathrm{kg}^{-1}$ ) and $\mathrm{H}_{2}$-receptor block (ranitidine, $20 \mathrm{mg} \mathrm{kg}^{-1}$, rattlesnakes only). Data points show means $\pm \mathrm{SEM}, N=4$ (a, b), and $N=5(\mathbf{c}, \mathbf{d})$. *Significant difference $(P<0.05)$ from pre-injection value evaluated by a one-way ANOVA for repeated measures followed by a HolmSidak post hoc test
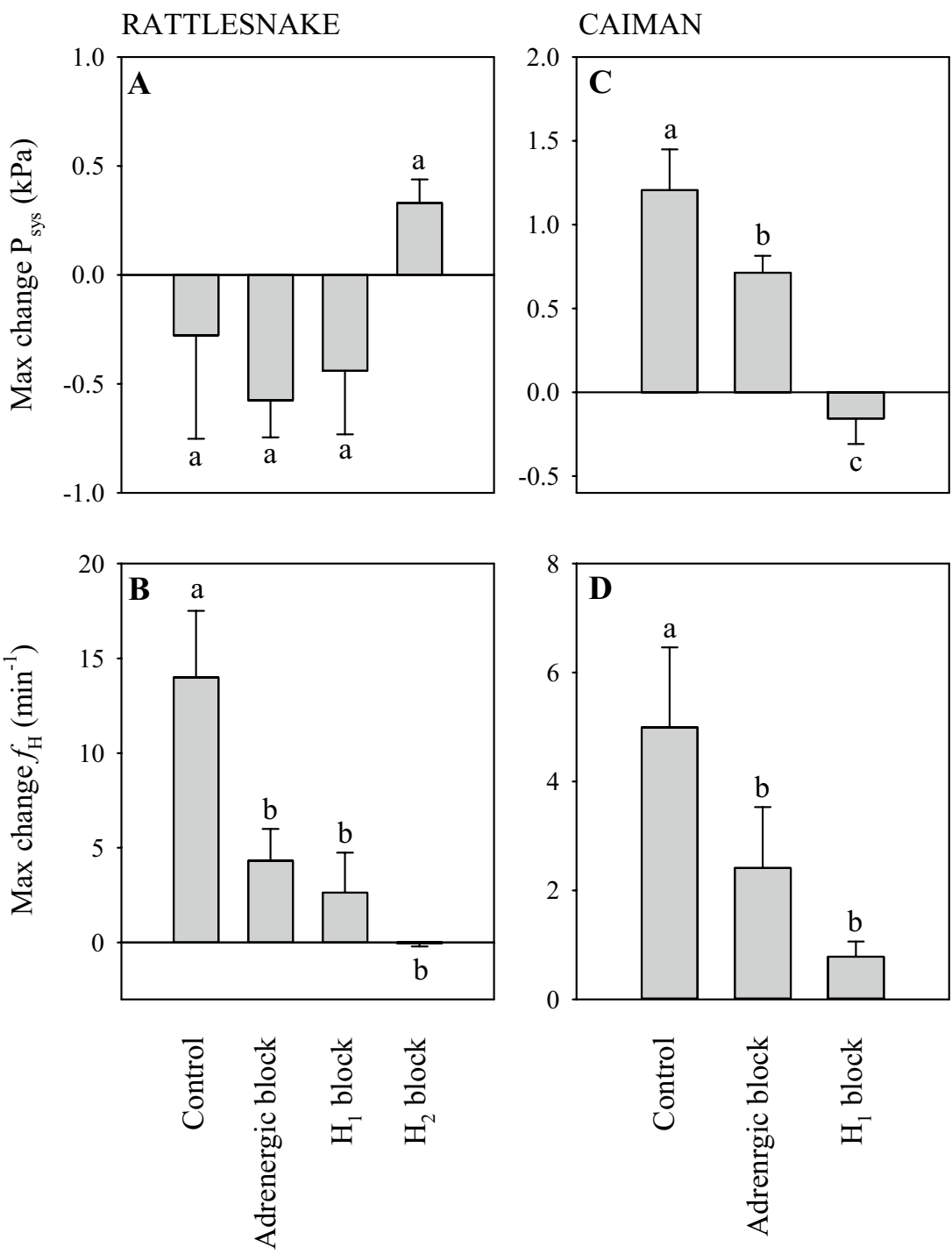

finding highlights a more complex mechanism underlying the action of histamine than previously recognized in reptiles (Skovgaard et al. 2009; Nørgaard et al. 2017).

\section{Vascular effects of histamine}

Histamine elicited dose-dependent effects in the systemic circulation in all three species of reptiles. In anesthetized turtles and caimans, histamine constricted the systemic vasculature, which led to an increase in systemic blood pressure. In contrast, histamine caused a systemic dilation and decrease in blood pressure in anesthetized rattlesnakes. In addition, in anesthetized rattlesnakes, blocking $\mathrm{H}_{1}$-receptors constricted the systemic vasculature and increased systemic blood pressure, which would suggest that histamine contributes to a basal vascular tone dilating the systemic circulation through $\mathrm{H}_{1}$-receptors. In recovered rattlesnakes, histamine decreased systemic blood pressure probably due to a systemic dilation as in anesthetized animal. This depressor effect persisted after double adrenergic and $\mathrm{H}_{1}$-receptor blockade. However, after injection of the $\mathrm{H}_{2}$-receptor antagonist, although statistically insignificant, the depressor was reversed to a pressor effect, suggesting that histamine dilates the systemic vasculature through $\mathrm{H}_{2}$-receptors in rattlesnakes. In recovered caimans, histamine caused an increase in systemic blood pressure probably due to a constriction of the systemic vasculature. The pressor effect was reduced after double adrenergic blockade indicating that there is an adrenergic component to the histamine-induced vasoconstriction. However, the attenuated effect of histamine on blood pressure might also be due to the reduced effect of histamine on heart rate after double adrenergic blockade. The effect of histamine on blood pressure was abolished by the $\mathrm{H}_{1}$-antagonist showing that histamine constricts the vasculature through $\mathrm{H}_{1}$-receptors. In a different study on pythons, histamine caused a dilation 
of the systemic circulation, and the effect persisted after $\beta$-adrenergic and muscarinic blockade showing that the vasodilation was not mediated through either the adrenergic or parasympathetic systems (Skovgaard et al. 2009). Furthermore, the dilation was abolished after the histamine $\mathrm{H}_{2}$-receptor blockade showing that the dilation was mediated directly through $\mathrm{H}_{2}$-receptors in the vasculature. No direct evidence for vascular $\mathrm{H}_{1}$-receptors was found in the python, although the depressor effect of histamine was reversed to a slight pressor response after $\mathrm{H}_{2}$-receptor blockade. However, in vitro studies in other reptiles have revealed both a dominant inhibitory effect of histamine causing vasodilation through $\mathrm{H}_{2}$-receptors and a stimulatory effect causing vasoconstriction mediated through $\mathrm{H}_{1}$-receptors (Reite 1970; Baysal 1977). In mammals, histamine dilates the systemic circulation through both $\mathrm{H}_{1}$-receptors in the endothelium and $\mathrm{H}_{2}$-receptors directly on the vascular smooth muscle cells (Dale and Laidlaw 1910; Black et al. 1975).

There were virtually no effects of histamine on the pulmonary vasculature in any of the three species. In rattlesnakes, the large decrease in pulmonary flow and pressure was merely the consequence of increased right-to-left shunt in response to the dilation of the systemic vasculature. In anesthetized rattlesnakes, however, the $\mathrm{H}_{1}$-antagonist mepyramine decreased pulmonary conductance and increased pulmonary flow and pressure. This might suggest that there is a histaminergic vascular tone dilating the pulmonary vasculature through $\mathrm{H}_{1}$-receptors in rattlesnakes. In mammals, histamine causes constriction of the pulmonary vasculature through histamine $\mathrm{H}_{1}$-receptors (Dale and Laidlaw 1910; Parsons and Ganellin 2006). The lack of effects of histamine on the pulmonary vasculature in the three reptilian species is consistent with similar studies revealing benign effects of various regulatory peptides and nitric oxide in the pulmonary circulation of numerous other reptiles (Skovgaard and Wang 2006).

\section{Cardiac effects of histamine}

Histamine exerted a powerful stimulation of $f_{\mathrm{H}}$ in all three species. In anesthetized caimans, the response was biphasic with a bradycardia followed by tachycardia, whereas the recovered animals only exhibited the tachycardia. This confirms another in vivo study showing a pronounced tachycardia in response to histamine injections in fully recovered snakes (Skovgaard et al. 2009; Nørgaard et al. 2017). Histamine also stimulates heart rate in mammals (Bristow et al. 1982), where three of the four identified histamine receptor types have been localized on the heart; receptor $\mathrm{H}_{1}$ and $\mathrm{H}_{2}$ are located in the cardiac tissue, whereas $\mathrm{H}_{3}$ is a pre-junctional synaptic receptor (Hill et al. 1997; Imamura et al. 1995). The primary and direct effect of histamine in the mammalian heart includes an increase in sinus rate and an increase in force of contraction (Wolf and Levi 1986). The tachycardia is induced through an $\mathrm{H}_{2}$-receptor mediated enhancement of slow inward $\mathrm{Ca}^{2+}$ current that accelerates the pacemaker potential (Wolf and Levi 1986). Previous studies on reptiles indicate that histaminergic effects on the heart vary among species and that the chronotropic effect is often weak or even absent, although histamine causes a marked increase in frequency of the spontaneous beating right atrium of the rainbow lizard (Kiniwa and Tasaka 1989; Ojewole and Akinwande 1984; Reite 1972).

In both recovered rattlesnakes and recovered caimans, the stimulatory effect of histamine was strongly attenuated by adrenergic blockade. In caimans, the $\mathrm{H}_{1}$-receptor antagonist further reduced $(P=0.06)$ the cardiac effect of histamine, whereas in rattlesnakes, the $\mathrm{H}_{2}$-antagonist abolished the histamine-induced tachycardia, although not statistically significant. This indicates an adrenergic component of the cardiac histamine response, in addition to the direct effect of histamine on $\mathrm{H}_{2}$-receptors previously shown in pythons and embryonic turtles as well as on $\mathrm{H}_{1}$-receptors (Skovgaard et al. 2009; Crossley et al. 2013; Nørgaard et al. 2017). A study on recovered pythons (Nørgaard et al. 2017) demonstrated that the indirect component was due to a myocardial histamine-induced catecholamine release, which strengthens the sympathetic adrenergic signaling pathway. The existence of a histamine-induced catecholamine release has also been suggested in mammals (Subramanian and Mulder 1977; Flacke et al. 1967; Laher and McNeill 1980a, b).

\section{Physiological significance (perspectives)}

Our study reveals intra-specific differences in the cardiovascular responses to histamine. In all three species, histamine induces tachycardia; however, in turtle and crocodile, histamine constricts the systemic vasculature, whereas in rattlesnakes, histamine dilates the systemic vasculature. This suggests that histamine plays different roles in these species.

Both turtles and crocodiles are semi-aquatic with the capacity for prolonged submergence. In particular, some species of fresh water turtles go through cold winters submerge in ice-cold water (Jackson 2000). Reite (1973) showed that submersion or cold exposure causes a substantial decrease in the histamine content of blood and an increase in the histamine content in the liver in many species of freshwater turtles. This is due to the migration of basophil leucocyte, which are exceptionally numerous in some species of fresh water turtles and contain a large amount of histamine, to the liver. Given our findings, it is possible that lowering the content of histamine in the blood would decrease heart rate and constrict the systemic 
vasculature of turtles. In fact, submerged or cold turtles are characterized by bradycardia and systemic vascular constriction (Burggren 1988; Stecyk et al. 2004). Stecyk et al. (2004) found a large increase in systemic resistance in cold acclimated anoxic turtles, which apparently was not mediated by an increase in adrenergic vasomotor tone and suggested that systemic resistance may be regulated by a nonadrenergic non-cholinergic factor. Thus, histamine may contribute to the regulation of the cardiovascular responses to submergence or cold. The content of histamine in mast cells and blood basophils in other species of reptiles including Caiman crocodilus is also very high (Reite 1972). Consequently, whether submergence and cold exposure are consistently associated with a migration of blood basophil leucocytes in these species remains elusive.

On the other hand, in both rattlesnakes and pythons (Skovgaard et al. 2009), histamine induces a strong tachycardia and dilates the systemic vasculature. Overall, these histaminergic effects resemble the cardiovascular response to the elevated metabolic rate during digestion, and we have previously documented an important role of increased histaminergic tone on the heart during the initial $24 \mathrm{~h}$ of digestion in pythons (Skovgaard et al. 2009). Thus, histamine seems to exert an important regulation of the cardiovascular system during digestion in snakes, which may be particular important in the large ambush predators capable of ingesting large meals relative to body size including pythons, rattlesnakes, and other snakes belonging to the Families of Pythonidae, Boidae, and the Subfamily Crotalinae.

Acknowledgements This study was supported by the Danish Research Council. EWT was supported in Brazil by FAPESP (2012/06938-8) and is currently a Visiting Researcher with the Science Without Borders Programme (CNPq 401061/2014-0).

\section{References}

Baysal F (1977) A study about the possible characteristics of cardiovascular histamine receptors of the turtle. Agents Actions 7:13-17

Black JW, Owen DAA, Parsons ME (1975) An analysis of the depressor responses to histamine in the cat and dog: involvement of both $\mathrm{H}_{1}$ - and $\mathrm{H}_{2}$-receptors. Br J Pharmacol 54:319-324

Bristow MR, Ginsburg R, Harrison DC (1982) Histamine and the heart: the other receptor system. Am J Cardiol 49:249-251

Burggren W (1988) Cardiovascular responses to diving and their relation to lung and blood oxygen stores in vertebrates. Can J Zool 66:20-28

Crossley DA II, Sartori MR, Abe AS, Taylor EW (2013) A role for histamine in cardiovascular regulation in late stage embryos of the red-footed tortoise, Chelonoidis carbonaria Spix, 1824. J Comp Physiol B 183:811-820

Dale HH, Laidlaw PP (1910) The physiological action of $\beta$-iminazolyl-ethylamine. J Physiol 41:318-344

Enok S, Simonsen LS, Pedersen SV, Wang T, Skovgaard N (2012) Humoral regulation of heart rate during digestion in pythons (Python molurus and Python regius). Am J Physiol 302:R1176-R1183

Flacke W, Atanacković D, Gills RA, Alper MH (1967) The action of histamine on the mammalian heart. J Pharmacol Exp Ther $155: 271-278$

Hegedüs E, Kaslin J, Hiripi L, Kiss T, Panula P, Elekes K (2004) Histaminergic neurons in the central and peripheral nervous system of gastropods (Helix, Lymnaea): An immunocytochemical, biochemical, and electrophysiological approach. J Comp Neurol 475:391-405

Hicks J (1998) Cardiac shunting in reptiles: mechanisms, regulation, and physiological functions. In: Gans C, Gaunt AS (eds) Biology of the reptilia, morphology G, visceral organs, vol 19 . SSAR Press, Athens, pp 425-484

Hill SJ, Ganellin CR, Timmerman H, Schwartz JC, Shankley NP, Young JM, Schunack W, Levi R, Haas LV (1997) International union of pharmacology. XIII. Classification of histamine receptors. Pharmacol Rev 49:253-278

Imamura M, Seyedi N, Lander HM, Levi R (1995) Functional identification of histamine $\mathrm{H}_{3}$-receptors in the human heart. Circ Res 77:206-210

Jackson DC (2000) Living without oxygen: lessons from the freshwater turtle. Comp Biochem Physiol 125A:299-315

Kiniwa M, Tasaka K (1989) Histamine and its actions on isolated tissues of lower vertebrates. Methods Find Exp Clin Pharmacol 11:87-95

Laher I, McNeill JH (1980a) Effects of histamine in the isolated kitten heart. Can J Physiol Pharmacol 58:1256-1261

Laher I, McNeill JH (1980b) Effects of histamine on rat isolated atria. Can J Physiol Zool 58:1114-1116

Lautt WW (1989) Resistance or conductance for expression of arterial vascular tone. Microvasc Res 37:230-236

Li M, Hu J, Chen Z, Meng J, Wang H, Ma X, Luo X (2006) Evidence for histamine as a neurotransmitter in the cardiac sympathetic nervous system. Am J Physiol 291:H45-H51

Miki H, Inagaki N, Yamatodani A, Wada H (1992) Regional distribution of histamine in the brain of non-mammalian vertebrates. Brain Res 571:129-132

Morris JL, Nilsson S (1994) The circulatory system. In: Nilsson S, Holmgren S (eds) Comparative physiology and evolution of the autonomic nervous system. Harwood Academic Publishers, Chur, pp 193-246

Nørgaard S, Joyce W, Fuhlendorf M, Enok S, Skovgaard N, Wang $\mathrm{T}$ (2017) Histamine exerts both direct $\mathrm{H}_{2}$-mediated and indirect catecholaminergic effects on heart rate in pythons. Am J Physiol (under review)

O'Leary DS (1991) Regional vascular resistance vs. conductance: which index for baroreflex responses? Am J Physiol 260:H632-H637

Ojewole JA, Akinwande KI (1984) Effects of cholinomimetic drugs on reptilian atrial muscles. Methods Find Exp Clin Pharmacol 6:379-387

Parsons ME, Ganellin CR (2006) Histamine and its receptors. Br J Pharmacol 147:S127-S135

Reite OB (1970) The evolution of vascular smooth muscle responses to histamine and 5-hydroxytryptamine. III. Manifestation of dual actions of either amine in reptiles. Acta Physiol Scand 78:213-231

Reite OB (1972) Comparative physiology of histamine. Physiol Rev $52: 778-819$

Reite OB (1973) Redistribution of tissue histamine stores (basophil leucocytes) of turtles in response to submersion and cold exposure. Acta Physiol Scand 88:62-66

Schayer RW (1956) The origin and fate of histamine in the body. In: Wolstenholme GEW, O'Conner CM (eds) Ciba foundation 
symposium on histamine, J. and A. Churchill Ltd, London, pp $183-188$

Skovgaard N, Wang T (2006) Local control of pulmonary blood flow and lung structure in reptiles: Implications for ventilation perfusion matching. Respir Physiol Neurobiol 154:107-117

Skovgaard N, Møller K, Gesser H, Wang T (2009) Histamine induces postprandial tachycardia through a direct effect on cardiac $\mathrm{H}_{2}$-receptors in pythons. Am J Physiol 296A:R774-R785

Stecyk JA, Overgaard J, Farrell AP, Wang T (2004) $\alpha$-adrenergic regulation of systemic peripheral resistance and blood flow distribution in the turtle Trachemys scripta during anoxic submergence at $5^{\circ} \mathrm{C}$ and $21^{\circ} \mathrm{C}$. J Exp Biol 207:269-283

Subramanian N, Mulder AH (1977) Modulation by histamine of the efflux of radiolabeled catecholamines from rat brain slices. Eur J Pharmacol 43:143-152

Taylor EW, Andrade DV, Abe AS, Leite CAC, Wang T (2009) The unequal influences of the left and right vagi on the control of the heart and pulmonary artery in the rattlesnake, Crotalus durissus. J Exp Biol 212:145-151

Wang T, Smits AW, Burggren WW (1998) Pulmonary functions in reptiles. In: Gans C, Gaunt AS (eds) Biology of the reptilia, morphology G, visceral organs, vol 19. SSAR Press, Athens, pp 297-374

Wang T, Taylor EW, Andrade D, Abe AS (2001) Autonomic control of heart rate during forced activity and digestion in the snake Boa constrictor. J Exp Biol 204:3553-3560

White FN, Hicks JW, Ishimatsu A (1989) Relationship between respiratory state and intracardiac shunts in turtles. Am J Physiol 256:R240-R247

Wolf AA, Levi R (1986) Histamine and cardiac arrhythmias. Circ Res 58:1-16 